ISSN 0103-8478

\title{
Macrobrachium amazonicum: an alternative for microbiological monitoring of aquatic environments in Brazil
}

\author{
Macrobrachium amazonicum uma alternativa para o monitoramento \\ microbiológico de ambientes aquáticos no Brasil
}

\author{
Raimunda Sâmia Nogueira Brilhante ${ }^{\mathrm{I}^{*}}$ Manoel de Araújo Neto Paiva ${ }^{\mathrm{I}, \mathrm{II}}$ \\ Célia Maria de Souza Sampaio ${ }^{I I}$ Carlos Eduardo Cordeiro Teixeira ${ }^{I}$ Joyce Fonteles Ribeiro ${ }^{I}$ \\ Débora de Souza Collares Maia Castelo-Branco ${ }^{\mathrm{I}}$ Tereza de Jesus Pinheiro Gomes Bandeira ${ }^{\mathrm{I}}$ III \\ André Jalles Monteiro ${ }^{\mathrm{IV}}$ Rossana de Aguiar Cordeiro ${ }^{\mathrm{I}}$ José Júlio Costa Sidrim $^{\mathrm{I}}$ \\ Frederico Ozanan Barros Monteiro ${ }^{\mathrm{V}}$ José Luciano Bezerra Moreira $^{\mathrm{I}}$ \\ Marcos Fábio Gadelha Rocha ${ }^{\mathrm{I}, \text { II }}$
}

\section{ABSTRACT}

This study aimed to evaluate the role of the Amazon River prawn, Macrobrachium amazonicum, as carrier of Candida spp., by analyzing the correlation between Candida spp. from these prawns and their environment (surface water and sediment), through M13$P C R$ fingerprinting and RAPD-PCR. For this purpose, 27 strains of Candida spp. were evaluated. These strains were recovered from the gastrointestinal tract of adult M. amazonicum (7/27) from Catú Lake, Ceará State, Brazil and from the aquatic environment (surface water and sediment) of this lake (20/27). Molecular comparison between the strains from prawns and the aquatic environment was conducted by M13-PCR fingerprinting and RAPD-PCR, utilizing the primers M13 and $O P Q 16$, respectively. The molecular analysis revealed similarities between the band patterns of eight Candida isolates with the primer $M 13$ and 11 isolates with the primer OPQ16, indicating that the same strains are present in the digestive tract of $M$. amazonicum and in the aquatic environment where these prawns inhabit. Therefore, these prawns can be used as sentinels for environmental monitoring through the recovery of Candida spp. from the aquatic environment in their gastrointestinal tract.

Key words: Macrobrachium amazonicum prawn, environmental sentinel, Candida spp., pollution, monitoring.

\section{RESUMO}

Este estudo teve como objetivo avaliar o papel do camarão Macrobrachium amazonicum como carreador de Candida spp. do ambiente aquático, por meio da análise da correlação entre Candida spp. isoladas desse camarão e do seu ambiente (água de superfície e sedimento) através das técnicas de M13-PCR fingerprinting e RAPD-PCR. Para tanto, 27 cepas de Candida spp. foram avaliadas. Essas cepas foram recuperadas a partir do trato gastrointestinal de M. amazonicum adultos (7/27), oriundos da lagoa do Catú, Ceará, Brasil, e do meio aquático (águas superficiais e sedimentos) desse lago (20/27). A comparação molecular entre as cepas de camarões e o ambiente aquático foi conduzida por M13-PCR fingerprinting e RAPD-PCR, utilizando os iniciadores $M 13$ e OPQ16, respectivamente. A análise molecular revelou semelhanças entre os padrões de bandas de oito isolados de Candida com o iniciador M13 e 11 isolados com o primer $O P Q 16$, indicando que elas estão presentes no trato digestivo de $\boldsymbol{M}$. amazonicum e no ambiente aquático, onde esses camarões habitam. Portanto, essa espécie de camarão pode ser usada como sentinela para monitoramento ambiental através da recuperação de Candida spp. do ambiente aquático, a partir do seu trato gastrointestinal.

Palavras-chave: camarão Macrobrachium amazonicum, sentinela ambiental, Candida spp, poluição, monitoramento.

\section{INTRODUCTION}

Several studies have identified Candida spp. as potential biological indicators of environmental

IDepartmento de Patologia e Medicina Legal, Faculdade de Medicina, Programa de Pós-graduação em Microbiologia Médica, Centro Especializado em Micologia Médica (CEMM), Universidade Federal do Ceará (UFC). Rua Coronel Nunes de Melo, s/n, Rodolfo Teófilo. 60430-270, Fortaleza, CE, Brasil. E-mail: brilhante@ufc.br. *Autor para correspondência.

${ }^{\text {IF}}$ Faculdade de Veterinária, Programa de Pós-graduação em Ciências Veterinárias, Universidade Estadual do Ceará (UECE), Fortaleza, CE, Brasil.

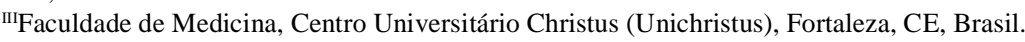

${ }^{\mathrm{IV}}$ Departmento de Estatística e Matemática Aplicada, UFC, Fortaleza, CE, Brasil.

vFaculdade de Medicina Veterinária, Programa de Pós-graduação em Saúde e Produção Animal da Amazônia, Universidade Federal Rural da Amazônia (UFRA), Belém, PA, Brasil. 
degradation (MEDEIROS et al., 2008; BRILHANTE et al., 2011, 2012; CASTELO-BRANCO et al., 2013), particularly in samples obtained from aquatic sources (BUTINAR et al., 2005; MEDEIROS et al., 2008). In these studies, the isolation of this genus was greater than that of other microorganisms, including bacteria, demonstrating the potential use of this yeast for environmental monitoring.

Monitoring aquatic environments requires an adequate water sampling technique, including the selection of representative collection sites and considering environmental factors, such as seasonality, temperature, the water column and the presence of affluent or effluent waters (APHA/AWWA/ WEF, 1998). These requirements may represent an obstacle for the adequate monitoring of fresh water environments, because of the large number of samples needed. Hence, it is important to seek alternatives to facilitate monitoring of aquatic ecosystems. In this context, the use of aquatic crustaceans has been reported as a reliable alternative for that purpose, especially because of their feeding habits (filter feeding) and benthic behavior, as described by VIRGA et al. (2007) and BRILHANTE et al. (2011).

More recently, BRILHANTE et al. (2011) performed a research with the freshwater prawn $\boldsymbol{M}$. amazonicum (Amazon River prawn) in captivity and from the natural environment for the isolation of yeasts and Candida was the most isolated genus, showing that it belongs to the gastrointestinal microbiota of these animals. In addition, these authors suggested that these prawns may be an important environmental sentinels if they harbor in their gastrointestinal tract Candida spp. from the aquatic environment. Thus, in light of these findings and considering the wide distribution of the species M. amazonicum in South America, the objective of the present study was to evaluate the role of these prawns as carriers of Candida spp. from the aquatic environment.

\section{MATERIALS AND METHODS}

\section{Microorganisms}

In this study, 27 strains of Candida spp. were analyzed, out of which seven were recovered from wild-harvested M. amazonicum, while 20 were recovered from the aquatic environment and were deposited in our culture collection. It is important to emphasize that the analyzed Candida strains, from animal and environmental sources, were simultaneously recovered.

Of the 20 environmental strains, 13 were isolated from surface water (SW) and seven from sediment $(\mathrm{S})$. These strains belong to the culture collection of the Specialized Medical Mycology Center of the Federal University of Ceará, where they are kept on $2 \%$ Sabouraud dextrose agar. They were manipulated under level II biosafety procedures.

Candida spp. from the aquatic environment were obtained from Catú Lake, which is located at the municipality of Aquiraz, Ceará state, Brazil, about 35 kilometers from the state capital. It is delimited by the UTM coordinates $0567000 \mathrm{E}, 9561273 \mathrm{~N}$ and $0575000 \mathrm{E}, 9569000 \mathrm{~N}$. It is a rich freshwater body with mangrove areas that have been degraded by uncontrolled occupation of the surrounding area and pollution with residues from industrial, commercial and farming activities (BRILHANTE et al., 2011).

Water samples were collected, according to MEDEIROS et al. (2008). Then, four collection sites were included, as follows: recreational area and prawn collection site (point $1,3^{\circ} 55^{\prime} 59.79$ " S and $38^{\circ} 21^{\prime} 50.10^{\prime \prime} \mathrm{W}$ ), agricultural wastewater (point 2, $3^{\circ} 55^{\prime} 47.25^{\prime \prime} \mathrm{S}$ and $38^{\circ} 22^{\prime} 14.16^{\prime \prime} \mathrm{W}$ ), industrial

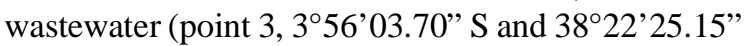
$\mathrm{W}$ ) and residential area (point 4, 3 ${ }^{\circ} 56^{\prime} 56.72^{\prime \prime} \mathrm{S}$ and $38^{\circ} 22^{\prime} 31.57^{\prime}$ W). Two water samples (SW and S) were monthly collected from each collection site, during one year (from March 2011 to February 2012). Overall, a total of 96 water samples were obtained for this study.

Adults of M. amazonicum were monthly harvested from Catú Lake (point 1) in the same period as the water samples. Afterwards, the digestive tracts of 10 individuals were removed, placed in sterile slants containing sterile saline and treated as one single sample (BRILHANTE et al., 2011). Overall, 12 collections were performed. This study was previously approved by the Chico Mendes Institute for Conservation of Biodiversity/Biodiversity Authorization and Information System - SISBIO, under the number 28175-1.

\section{Microbiological processing}

Samples were processed in a biosafety level II cabinet and were seeded on $2 \%$ Sabouraud agar plus chloramphenicol $\left(0.5 \mathrm{~g} \mathrm{~L}^{-1}\right)$, in Petri dishes for primary isolation. Water samples were processed according to MEDEIROS et al. (2008) with some modifications. Briefly, a $100-\mu \mathrm{L}$ aliquot of the SW samples was spread on the medium, after homogenization, while the $\mathrm{S}$ samples were processed, after centrifuging for 20 minutes at 3,000rpm. Then, the supernatant was removed and the substrate was suspended again in $2 \mathrm{~mL}$ of a sterile $0.9 \%$ solution of $\mathrm{NaCl}$. Afterwards, the suspension was agitated 
in a vortex mixer for 3 minutes and left to rest for 30 minutes at $25^{\circ} \mathrm{C}$. Next, $100-\mu \mathrm{L}$ aliquots of the supernatant of each sample were seeded on the culture medium. The digestive tracts of adult prawns were processed as described by BRILHANTE et al. (2011) and seeded onto the culture medium. The inoculated Petri dishes containing the culture media were incubated at $25^{\circ} \mathrm{C}$, for 10 days, and were daily observed (BRILHANTE et al., 2011).

The yeast colonies were identified through specific morphological and biochemical tests, including growth on chromogenic medium (CHROMagar Candida, BD, USA), micromorphology on cornmeal-Tween 80 agar, carbohydrate and nitrogen assimilation and urease production (BRILHANTE et al., 2011), and the results were interpreted according to (DE HOOG et al., 2000). Strains that presented dubious identity were also identified through VITEK II automated system (BioMérieux, USA). Additionally, the susceptibility of these microorganisms to amphotericin $\mathrm{B}$, fluconazole and itraconazole was evaluated through broth microdilution method. Minimum inhibitory concentrations (MIC) of $>1, \geq 64, \geq 1 \mu \mathrm{g} \mathrm{mL}^{-1}$ were considered resistant to amphotericin $\mathrm{B}$, fluconazole and itraconazole, respectively (CLSI, 2008).

\section{M13-PCR fingerprinting and OPQ-16 RAPD}

The DNA from the strains was extracted after 48 hours of growth on potato dextrose agar, according to the methodology described by CASTELO-BRANCO et al. (2013).

For molecular comparison between the Candida isolates from the aquatic environment (SW and S) and from prawns, the PCR-fingerprinting technique was used, according to the method described by CASTELO-BRANCO et al. (2013), using the single primer M13 (59-GAGGGTGGCG GTTCT-39) and the PCR mix $(25 \mu \mathrm{L})$, containing $10 \mathrm{mM}$ of Tris/ $\mathrm{HCI}(\mathrm{pH} 8.3), 50 \mathrm{mM}$ of $\mathrm{KCl}, 1.5 \mathrm{mM}$ of $\mathrm{MgCl} 2$, $0.2 \mathrm{mM}$ of dNTPs, $0.15 \mathrm{mM}$ of the primer, $2.5 \mathrm{U}$ of Taq polymerase (MBI Fermentas) and 25ng of yeast DNA. The RAPD reactions were performed with the primer OPQ16 (5' AAGAGCCCGT3'), according to the method described by CASTELO-BRANCO et al. (2013). The RAPD reaction was carried out with a total volume of $10 \mu \mathrm{L}$, containing $50 \mathrm{ng}$ of genomic DNA, $1 \mathrm{X}$ buffer, $1 \mathrm{mM}$ of $\mathrm{MgCl}_{2}, 2 \mathrm{pmol}$ of primer, $0.5 \mathrm{mM}$ each of deoxynucleoside triphosphate and 1 $\mathrm{U} \mu \mathrm{L}^{-1}$ of Hot Start Taq polymerase.

Dice similarity coefficient was measured and a dendrogram was obtained through the use of the Unweighted Pair Group Method with
Arithmetic Average (UPGMA), through the software BioNumerics (version 6.6), resulting in the analysis of clusters and measure of relatedness among isolates.

\section{RESULTS}

Data referring to the identity, the origin and the antifungal susceptibility profile of the recovered Candida strains are listed in table 1. Five to eight DNA bands were generated through the M13-PCR fingerprinting, while three to ten DNA bands were generated through RAPD-PCR with the primer OPQ16. The molecular analysis employing both techniques revealed strong similarities between the DNA band patterns of the isolates belonging to the same Candida species. For the primer M13, eight isolates of Candida spp. with $100 \%$ band similarity were obtained, while with the primer OPQ16, 11 isolates were obtained with $100 \%$ band similarity (Figure 1).

The M13-PCR fingerprinting identified $100 \%$ similarity between two $\boldsymbol{C}$. tropicalis strains from prawn $(\mathrm{n}=1)$ and sediment (point $3, \mathrm{n}=1$ ); four C. famata strains from prawns $(\mathrm{n}=2)$ and surface water (points 1 and $3 ; n=2$ ) and two $\boldsymbol{C}$. ciferrii strains from prawns $(n=1)$ and sediment (point 1, $n=1$ ). In turn, the RAPD-PCR with the primer OPQ16 allowed identifying $100 \%$ similarity between two C. guilliermondii strains from surface water (points 1 and 4); five $\boldsymbol{C}$. famata strains, two from prawn $(n=1)$ and surface water (point $1, n=1)$ and three from surface water (points 1 and 2); two strains of C. parapsilosis from prawn $(\mathrm{n}=1)$ and surface water (point 4, n=1) and two $\boldsymbol{C}$. ciferrii strains from prawn $(\mathrm{n}=1)$ and sediment (point 1, $\mathrm{n}=1)$ (Figure 1).

\section{DISCUSSION}

This study demonstrated the similarity among Candida spp. isolated from wild-harvested prawns and the aquatic environment where the animals inhabit, including surface water and sediment. The molecular analysis through M13-PCR fingerprinting and RAPD-PCR with OPQ-16 allowed evaluating this correlation, since these techniques generated varied band patterns among different Candida species and similar ones within the same species, thus presenting desirable and reliable results. In the present study, the primer OPQ16 was used to complement the results obtained through the M13PCR fingerprinting and it generated a greater variety of DNA bands and identified a greater number of strains with $100 \%$ of similarity.

Ciência Rural, v.44, n.11, nov, 2014. 
Table 1 - Species, access number, origin, isolation period and antifungal susceptibility of 27 Candida spp. isolates used for molecular analysis.

\begin{tabular}{|c|c|c|c|c|c|}
\hline Species & Access number & Origin & Collection point & Period & Resistance* \\
\hline C. famata & CEMM 1-1-259 & Sediment & Point 3 & October 2011 & FLC/ITC \\
\hline C. guilliermondii & CEMM 1-1-260 & Surface Water & Point 4 & November 2011 & ITC \\
\hline C. guilliermondii & CEMM 1-1-261 & Sediment & Point 4 & November 2011 & $\mathrm{~S}$ \\
\hline C. famata & CEMM 1-1-262 & Sediment & Point 3 & November 2011 & $\mathrm{~S}$ \\
\hline C. guilliermondii & CEMM 1-1-263 & Prawn & Point 1 & December 2011 & $\mathrm{~S}$ \\
\hline C. famata & CEMM 1-1-264 & Prawn & Point 1 & November 2011 & $\mathrm{~S}$ \\
\hline C. famata & CEMM 1-1-265 & Prawn & Point 1 & November 2011 & ITC \\
\hline C. parapsilosis & CEMM 1-1-266 & Surface Water & Point 4 & November 2011 & $\mathrm{~S}$ \\
\hline C. famata & CEMM 1-1-267 & Surface Water & Point 1 & August 2011 & ITC \\
\hline C. parapsilosis & CEMM 1-1-268 & Prawn & Point 1 & March 2011 & $\mathrm{~S}$ \\
\hline C. ciferrii & CEMM 1-1-269 & Surface Water & Point 3 & October 2011 & $\mathrm{~S}$ \\
\hline C. ciferrii & CEMM 1-1-270 & Surface Water & Point 1 & August 2011 & ITC \\
\hline C. ciferrii & CEMM 1-1-271 & Sediment & Point 4 & November 2011 & $\mathrm{~S}$ \\
\hline C. ciferrii & CEMM 1-1-272 & Sediment & Point 1 & October 2011 & FLC/ITC \\
\hline C. ciferrii & CEMM 1-1-273 & Prawn & Point 1 & October 2011 & FLC/ITC \\
\hline C. famata & CEMM 1-1-274 & Surface Water & Point 3 & November 2011 & $\mathrm{~S}$ \\
\hline C. famata & CEMM 1-1-275 & Surface Water & Point 3 & May 2011 & $\mathrm{~S}$ \\
\hline C. famata & CEMM 1-1-276 & Surface Water & Point 1 & August 2011 & FLC/ITC \\
\hline C. famata & CEMM 1-1-277 & Prawn & Point 1 & December 2011 & $\mathrm{~S}$ \\
\hline C. famata & CEMM 1-1-278 & Surface Water & Point 4 & October 2011 & FLC \\
\hline C. parapsilosis & CEMM 1-1-279 & Surface Water & Point 1 & May 2011 & $\mathrm{~S}$ \\
\hline C. tropicalis & CEMM 1-1-280 & Prawn & Point 1 & October 2011 & FLC/ITC \\
\hline C. tropicalis & CEMM 1-1-281 & Sediment & Point 3 & October 2011 & FLC/ITC \\
\hline C. guilliermondii & CEMM 1-1-282 & Surface Water & Point 4 & December 2011 & $\mathrm{~S}$ \\
\hline C. guilliermondii & CEMM 1-1-283 & Sediment & Point 3 & December 2011 & $\mathrm{~S}$ \\
\hline C. guilliermondii & CEMM 1-1-284 & Surface Water & Point 4 & August 2011 & ITC \\
\hline C. guilliermondii & CEMM 1-1-285 & Surface Water & Point 1 & December 2011 & FLC/ITC \\
\hline
\end{tabular}

*All strains were susceptible to amphotericin B, S: susceptible to all tested antifungal drugs (amphotericin B, fluconazole and itraconazole); FLC: resistance to fluconazole; ITC: Resistance to itraconazole.

The recovered Candida species were simultaneously isolated from prawns and the aquatic environment and some of these isolates presented $100 \%$ similarity, even when recovered from different collection points. Thus, it was demonstrated that M. amazonicum contains in its gastrointestinal tract a representative cross-section of Candida spp. that colonize the water and the substrate where they live.

In addition, three sets of azole resistant strains were observed among the isolates from prawns and aquatic environment that presented $100 \%$ similarity. These findings are in accordance with those of BRILHANTE et al. (2011), who observed that $28.6 \%$ of the Candida spp. recovered from the intestinal tract of wild-harvested M. amazonicum isolated from Catú Lake were resistant to azole antifungals. Considering that the main mechanism of azole resistance among Candida spp. is the overexpression of efflux pumps (FENG et al., 2010), which is possibly related to the exposure of these microorganisms to chemical compounds, as an unspecific mechanism of cellular detoxification (JUNGWIRTH \& KUCHLER, 2006), we strongly believe that Candida spp. could be used as indicators of environmental pollution, through the phenotypical assessment of their in vitro susceptibility profile.

Crustaceans accumulate pollutants in their tissues, such as hydrocarbons, pesticides and heavy metals (YILMAZ \& YILMAZ, 2007), which might increase the azole resistance rate among yeasts from the microbiota, due to the overexpression of efflux pumps (KEENAN et al., 2007; MÜLLER et al., 2007), as a consequence of the chronic exposure to these chemical compounds. In this context, the use of this prawn as a sentinel for the isolation of Candida spp. seems potentially advantageous. 

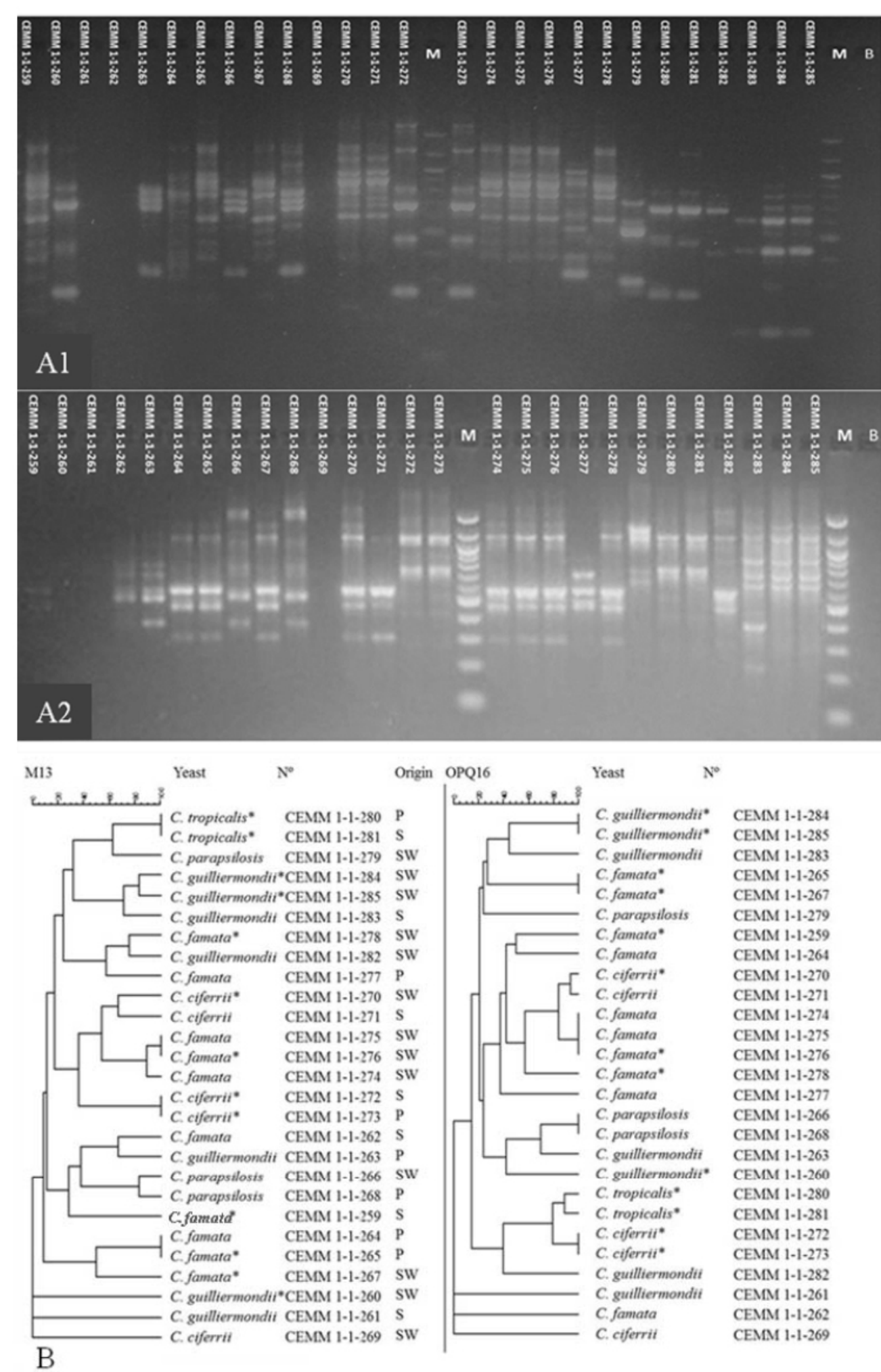

CEMM 1-1-284

CEMM 1-1-285

CEMM 1-1-283

CEMM 1-1-265

CEMM 1-1-267

CEMM 1-1-279

CEMM 1-1-259

CEMM 1-1-264

CEMM 1-1-270

CEMM 1-1-271

CEMM 1-1-274

CEMM 1-1.275

CEMM 1-1-276

CEMM 1-1-278

CEMM 1-1-277

CEMM 1-1.266

CEMM 1-1-268

CEMM 1-1-263

CEMM 1-1-260

CEMM 1-1-280

CEMM 1-1-281

CEMM 1-1-272

CEMM 1-1-273

CEMM 1-1-282

CEMM 1-1-261

CEMM 1-1-262

CEMM 1-1-269

Figure 1 - Dendrograms resulting from the analysis of 27 isolates of Candida spp. obtained from the gastrointestinal tract of Macrobrachium amazonicum $(\mathrm{n}=7)$ and the natural environment $(\mathrm{n}=20)$ through M-13fingerprinting and RAPD-PCR with primer OPQ16. P: prawn; SW: surface water; S: sediment. *indicates antifungal resistance. Dendrograms generated by the BioNumerics program (Applied Math, Inc.). 


\section{CONCLUSION}

In conclusion, based on the obtained results, the use of $\boldsymbol{M}$. amazonicum as a sentinel for the isolation of Candida spp. from aquatic environments is an interesting alternative for evaluating the environmental quality, considering that these animals harbor yeasts from the environment in their gastrointestinal tract. Additionally, due to their capacity to accumulate chemical pollutants in their tissues, they simulate the environmental conditions to which these yeasts are exposed, potentially contributing for monitoring the presence of resistant Candida spp. in the environment.

\section{ACKNOWLEDGEMENTS}

This research was supported by grants from the National Council for Scientific and Technological Development (CNPq; Brazil; Processes 302574/2009-3, 481614/2011-7, 504189/2012-3) and the Coordination Office for the Improvement of Higher Education Personnel (CAPES/PNPD 2103/2009, AE10052-000650100/11, Casadinho/PROCAD 552215/2011-2).

\section{REFERENCES}

AMERICAN PUBLIC HEALTH ASSOCIATION (APHA); AMERICAN WATER WORKS ASSOCIATION (AWWA); WATER ENVIRONMENTAL FEDERATION (WEF). Standard methods for the examination of water and wastewater. 20.ed. Washington, 1998. 64p.

BRILHANTE, R.S.N. et al. Yeast microbiota of raptors: a possible tool for environmental monitoring. Environmental Microbiology Reports, v.4, n.2, p.189-193, 2012. Available from: <http:// onlinelibrary.wiley.com/doi/10.1111/j.1758-2229.2011.00319.x/ abstract>. Accessed: Nov. 08, 2013. doi: 10.1111/j.17582229.2011.00319.x.

BRILHANTE, R.S.N. et al. Yeasts from Macrobrachium amazonicum: a focus on antifungal susceptibility and virulence factors of Candida spp. FEMS Microbiology Ecology, v.76, n.2, p.268-277, 2011. Available from: <http://onlinelibrary.wiley.com/ doi/10.1111/j.1574-6941.2011.01050.x/abstract>. Accessed: Nov. 08, 2013. doi: 10.1111/j.1574-6941.2011.01050.x.

BUTINAR, L. et al. Yeast diversity in hypersaline habitats. FEMS Microbiology Letters, v.15, n.2, p.229-234, 2005. Available from: <http://onlinelibrary.wiley.com/doi/10.1016/j.femsle.2005.01.043/ pdf>. Accessed: Nov. 08, 2013. doi:10.1016/j.femsle.2005.01.043.

CASTELO-BRANCO, D.S.C.M. et al. Azole-resistant Candida albicans from a wild Brazilian porcupine (Coendou prehensilis): a sign of an environmental imbalance? Medical Mycology, v.51, n.5, p.555-560, 2013. Available from: <http://informahealthcare. com/doi/abs/10.3109/13693786.2012.752878>. Accessed: Nov. 08, 2013. doi: $10.3109 / 13693786.2012 .752878$.

CLINICAL AND LABORATORY STANDARDS INSTITUTE. Reference method for broth dilution antifungal susceptibility testing of yeast: approved guideline M27-A3. Wayne, PA: CLSI, 2008. V.28, p.1-25.

DE HOOG, G.S. et al. Atlas of clinical fungi. 2.ed. The Nederlands: Centraalbureau voor Schimmelcultures, Baarn, 2000. 1126 p.

FENG, L. et al. Relationship between antifungal resistance of fluconazole resistant Candida albicans and mutations in ERG11 gene. Chinese Medical Journal, v.123, n.5, p.544-548, 2010. Available from: <http://www.cmj.org/ch/reader/view_abstract_ ext.aspx?file no $=20103842232480 \&$ flag $=1>$. Accessed: Dec. 20 , 2013. doi: $10.3760 / \mathrm{cma}$.j.issn.0366-6999.2010.05.007.

JUNGWIRTH, H.; KUCHLER, K. Yeast ABC transporters - a tale of sex, stress, drugs and aging. FEBS Letters, v.580, n.4, p.1131-1138, 2006. Available from: <http://www.sciencedirect. com/science/article/pii/S0014579305015334>. Accessed: Dec. 20, 2013. doi:10.1016/j.febslet.2005.12.050.

KEENAN, P.O. et al. Clear and present danger? The use of a yeast biosensor to monitor changes in the toxicity of industrial effluents subjected to oxidative colour removal treatments. Journal of Environmental Monitoring, v.9, n.12, p.13941401, 2007. Available from: <http://pubs.rsc.org/en/Content/ ArticleLanding/2007/EM/b710406e\#!divAbstract>. Accessed: Nov. 08, 2013. doi: 10.1039/B710406E.

MEDEIROS, A.O. et al. Diversity and antifungal susceptibility of yeasts from tropical freshwater environments in Southeastern Brazil. Water Research, v.42, n.14, p.3921-3929, 2008. Disponível em: <http://www.sciencedirect.com/science/article/pii/ S0043135408002522>. Accessed: Nov. 08, 2013. doi: 10.1016/j. watres.2008.05.026

MÜLLER, F.M.C. et al. Cross-resistance to medical and agricultural azole drugs in yeasts from the oropharynx of human immunodeficiency virus patients and from environmental bavarian vine grapes. Antimicrobial Agents and Chemotherapy, v.51, n.8, p.3014-3016, 2007. Available from: <http://aac.asm.org/ content/51/8/3014.long>. Accessed: Nov. 08 2013. doi:10.1128/ AAC.00459-07.

VIRGA, R.H.P. et al. Assessment of heavy metal contamination in blue crab specimes. Food Science and Technology, v.27, n.4, p.779-785, 2007. Available from: <http://www.scielo. br/scielo.php?pid=S0101-20612007000400017\& script $=$ sci arttext $>$. Accessed: Nov. 08, 2013. doi: 10.1590/S010120612007000400017

YILMAZ, A.B.; YILMAZ, L. Influences of sex and seasons on levels of heavy metals in tissues of green tiger shrimp (Penaeus semisulcatus de Hann, 1844). Food Chemistry, v.101, n.4, p.1664-1669, 2007. Available from: <http://www.sciencedirect. com/science/article/pii/S0308814606003438>. Accessed: Nov. 08, 2013. doi: 10.1016/j.foodchem.2006.04.025. 